\title{
Assessment of Groundwater Quality and its Suitability for Drinking and Agricultural Uses in the Oshnavieh Area, Northwest of Iran
}

\author{
Nosrat Aghazadeh $^{1 *}$, Asghar Asghari Mogaddam² \\ ${ }^{1}$ Department of Geology, Urmia Azad University, Urmia, Iran; ${ }^{2}$ Department of Geology, Tabriz University, Tabriz, Iran. \\ Email: nosrataghazadeh@Yahoo.com,n.aghazadeh@iaurmia.ac.ir
}

Received December $8^{\text {th }}, 2009$; revised February $27^{\text {th }}, 2010$; accepted February $28^{\text {th }}, 2010$.

\begin{abstract}
The Oshnavieh plain is part of the West Azarbaijan province, which is located; $100 \mathrm{~km}$ south of Urmia City, northwestern of Iran, and its groundwater resources are developed for water supply and irrigation purposes. In order to evaluate the quality of groundwater in study area, 31 groundwater samples were collected and analyzed for various parameters. Physical and chemical parameters of groundwater such as electrical conductivity, $\mathrm{pH}$, total dissolved solids, $\mathrm{Na}, \mathrm{K}, \mathrm{Ca}$, $\mathrm{Mg}, \mathrm{Cl}, \mathrm{HCO}_{3}, \mathrm{CO}_{3}, \mathrm{SO}_{4}, \mathrm{NO}_{3}, \mathrm{NH}_{3}, \mathrm{PO}_{4}, \mathrm{Fe}, \mathrm{F}$ were determined. Chemical index like percentage of sodium, sodium adsorption ratio, and residual sodium carbonated, permeability index $(P I)$ and chloroalkaline indices were calculated. Based on the analytical results, groundwater in the area is generally fresh and hard to very hard. The abundance of the major ions is as follows: $\mathrm{HCO}_{3}>\mathrm{SO}_{4}>\mathrm{Cl}$ and $\mathrm{Ca}>\mathrm{Mg}>\mathrm{Na}>\mathrm{K}$. The dominant hydrochemical facieses of groundwater is $\mathrm{Ca}-\mathrm{HCO}_{3}$ and $\mathrm{Ca}-\mathrm{Mg}-\mathrm{HCO}_{3}$ type. According to Gibbs diagrams samples fall in the rock dominance field and the chemical quality of groundwater is related to the lithology of the area. The results of calculation saturation index by computer program PHREEQC shows that the nearly all of the water samples were saturated to undersaturated with respect to carbonate minerals and undersaturated with respect to sulfate minerals. Assessment of water samples from various methods indicated that groundwater in study area is chemically suitable for drinking and agricultural uses. Fluoride and nitrate are within the permissible limits for human consumption and crops as per the international standards.
\end{abstract}

Keywords: Groundwater Quality, Hydrochemistry, Hydrogeology, Oshnavieh Plain, Water Type

\section{Introduction}

Understanding the aquifer hydraulic properties and hydrochemical characteristics of water is crucial for groundwater planning and management in the study area. Generally, the motion of groundwater along its flow paths below the ground surface increases the concentration of the chem. ical species [1-3]. Hence, the groundwater chemistry could reveal important information on the geological history of the aquifers and the suitability of groundwater for domestic, industrial and agricultural purposes. Moreover, pumping tests with the drilling results are the most important information available for the groundwater investigations, as they are the only methods that provide information on the hydraulic behavior of wells and reservoir boundaries $[4,5]$.

Hydrochemical evaluation of groundwater systems is usually based on the availability of a large amount of information concerning groundwater chemistry $[6,7]$. Quality of groundwater is equally important to its quan- tity owing to the suitability of water for various purposes $[8,9]$. Groundwater chemistry, in turn, depends on a number of factors, such as general geology, degree of chemical weathering of the various rock types, quality of recharge water and inputs from sources other than waterrock interaction. Such factors and their interactions result in a complex groundwater quality $[1,10,11]$. The rapid increase in the population of the country has led to large scale groundwater developments in some areas. Intense agricultural and urban development has caused a high demand on groundwater resources in arid and semi-arid regions of Iran while putting these resources at greater risk to contamination [12-14]. Groundwater is an important water resource for drinking, agriculture and industrial uses in study area. In this study, physical, hydrogeologic, and hydrochemical data from the groundwater system will be integrated and used to determine the main factors and mechanisms controlling the chemistry of groundwater in the area. The relationship between groundwater flow, hydrogeologic properties and hydro- 
chemistry has been studied by many researchers $[2,15$, $16]$. The chemical quality of groundwater is related to the lithology of the area.

The Oshnavieh aquifer is part of the Gedar river drainage basin and lies between latitudes $36^{\circ}, 57^{\prime}$ to $37^{\circ}, 05^{\prime} \mathrm{N}$ and longitudes $45^{\circ}, 01^{\prime}$, to $45^{\circ}, 15^{\prime} \mathrm{E}$. Oshnavieh plain covers an area of $120 \mathrm{~km}^{2}$ and average elevation is $1450 \mathrm{~m}$ a.s.l. (Figure 1). The Gedar river basin covers approximately $2010 \mathrm{~km}^{2}$ and river flow direction is almost west-east with utmost discharges into the Urmia lake. The most important drainage feature of the study area is the Oshnavieh, Nilvan and Sheykhan rivers. The area has a cold temperate climate and the air temperature is highest in August $\left(26.7^{\circ} \mathrm{C}\right)$ and lowest in January $\left(-1^{\circ} \mathrm{C}\right)$ with an annual average of $13.3^{\circ} \mathrm{C}$. The climate of the study area is semi-arid and it's average annual rainfall is about $422 \mathrm{~mm}$, which $70 \%$ of it falls during the spring and winter seasons. The most important economic activity in the area is agriculture, with the chief crops being beet, wheat and pea.

\section{Materials and Methods}

Groundwater samples were collected from 31 shallow and deep wells and springs of the area during May 2006. The location of sampling points is shown in Figure 4. The $\mathrm{pH}$ and electrical conductivity (EC) were measured using digital conductivity meters immediately after sampling. Water sample collected in the field were analyzed in the laboratory for the major ions $(\mathrm{Ca}, \mathrm{Mg}, \mathrm{Na}$,
$\left.\mathrm{K}, \mathrm{HCO}_{3}, \mathrm{CO}_{3}, \mathrm{SO}_{4}, \mathrm{Cl}\right)$, nitrate, phosphate, ammonia, iron and fluorine using the standard methods as suggested by the American Public Health Association [17]. Sodium $(\mathrm{Na})$ and Potassium $(\mathrm{K})$ were determined by flame photometer. Total hardness (TH) as $\mathrm{CaCO}_{3}$, Calcium $\left(\mathrm{Ca}^{2+}\right)$, carbonate $\left(\mathrm{CO}_{3}\right)$, bicarbonate $\left(\mathrm{HCO}_{3}\right)$ and chloride $(\mathrm{Cl})$ were analyzed by volumetric methods. Magnesium (Mg) was calculated from $\mathrm{TH}$ and $\mathrm{Ca}$ contents. Sulfates $\left(\mathrm{SO}_{4}\right)$ were estimated using the colorimetric technique. Nitrate $\left(\mathrm{NO}_{3}\right)$, phosphate $\left(\mathrm{PO}_{4}\right)$, ammonia $\left(\mathrm{NH}_{3}\right)$, iron $(\mathrm{Fe})$ and fluorine $(\mathrm{F})$ were determined by spectrophotometer. The saturation indexes were determined using the hydrogeochemical equilibrium model, Phreeqc for Windows [18].

\section{Results and Discussion}

\subsection{Geological and Hydrogeological Stting}

From a geological point of view, the investigated area is located in the Khoy-Mahabad zone of the Iran [19]. Igneous, metamorphic and sedimentary rocks of different age's crop out in the basin and range in age from Percambrian to Quaternary. Precambrian sedimentary rocks consist of green to grey shale and siltstone. Cambrian formations in study area chiefly comprise crystalline limestone, siltstone, sandstone and dolomite in alternation with dark shale. The Ophiolite formation consists of crystallized limestone and shale with serpentinized ultramafic rocks, spite and some schist [20]. Igneous rocks of late Cretaceous age outcrop in many mountain and

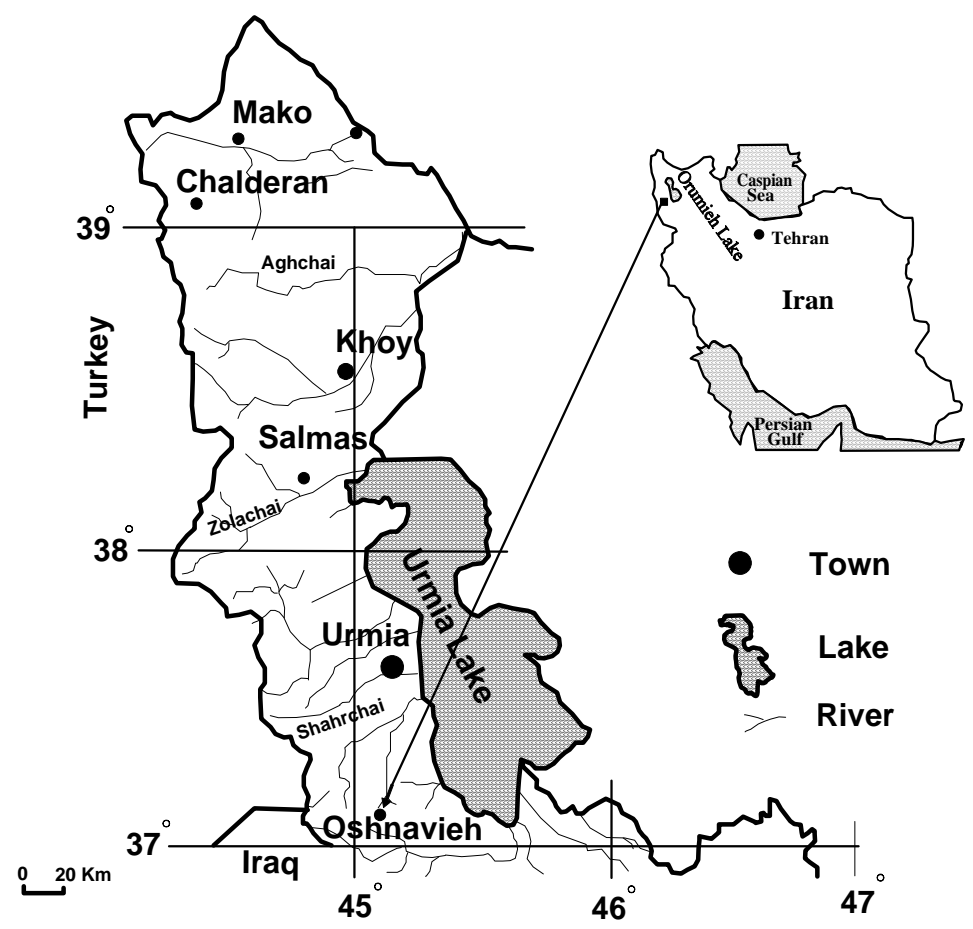

Figure 1. Location of study area in iran 
including biotite granite, muscovite garnet granite, diorite, monzodiorite and granodiorite. The Quaternary sediments consist of alluvial sandy gravel, alluvial fan consists of a clay, silt, sand, gravel and clearly sand. The thickness of this major aquifer increases from the fan deposits in the west towards the middle and southeast side of plain. Figure 2 shows the distribution of the outcropping rock formations in the study area. The basin is tectonically active and the most important structure that affected the geology of the Oshnavieh basin was the Aghbolag, Kandvola and Shivehbro fault system. The exposed lithological units of the Oshnavieh plain range in age from Precambrian to Quaternary and have different hydrogeological characteristics (Figure 2). The stratigraphic succession of study area shows in Table 1. The units of similar hydrogeological characteristics are summarized in Table 1 and qualitatively grouped as impermeable, semi-permeable and permeable.

In the study area, the Eocene Formations and intrusive rocks are impermeable, and the Cambrian formations (Zaigun, Lalum and Barut Formation) and Precambrian
Formations (Kahar Formation) are semi-permeable. The Ruteh Formation, alluvium and old terraces are permeable [21].

Table 1. Stratigraphic relations of the geologic units in the study area showing hydrogeologic properties

\begin{tabular}{|c|c|c|c|}
\hline Age & Unit & Lithology & $\begin{array}{c}\text { Hydrogeologic } \\
\text { properties }\end{array}$ \\
\hline Cenozoic & $\begin{array}{l}\text { Recent alluvium } \\
\text { Young alluvium } \\
\text { Old terraces }\end{array}$ & $\begin{array}{l}\text { Gravel, Sand, Clay, } \\
\text { Sandy clay and clearly } \\
\text { sand }\end{array}$ & Permeable \\
\hline Eocene & Ophiolite & $\begin{array}{l}\text { Limestone, Shale, } \\
\text { Spilite, Schist and } \\
\text { Serpentinite }\end{array}$ & impermeable \\
\hline Permian & Ruteh Formation & Limestone and Shale & Permeable \\
\hline Cambrian & $\begin{array}{l}\text { Zaigun, Lalum } \\
\text { and Barut } \\
\text { Formation }\end{array}$ & $\begin{array}{c}\text { Siltstone, Sandstone, } \\
\text { Shale, Limestone and } \\
\text { dolomite }\end{array}$ & semipermeable \\
\hline \multirow[t]{2}{*}{$\begin{array}{l}\text { Precam- } \\
\text { brian }\end{array}$} & Kahar Formation & $\begin{array}{l}\text { Schist, shale and } \\
\text { siltstone }\end{array}$ & semipermeable \\
\hline & & $\begin{array}{l}\text { Granite, Grano diorite, } \\
\text { Amphibolite and diabaz }\end{array}$ & impermeable \\
\hline
\end{tabular}

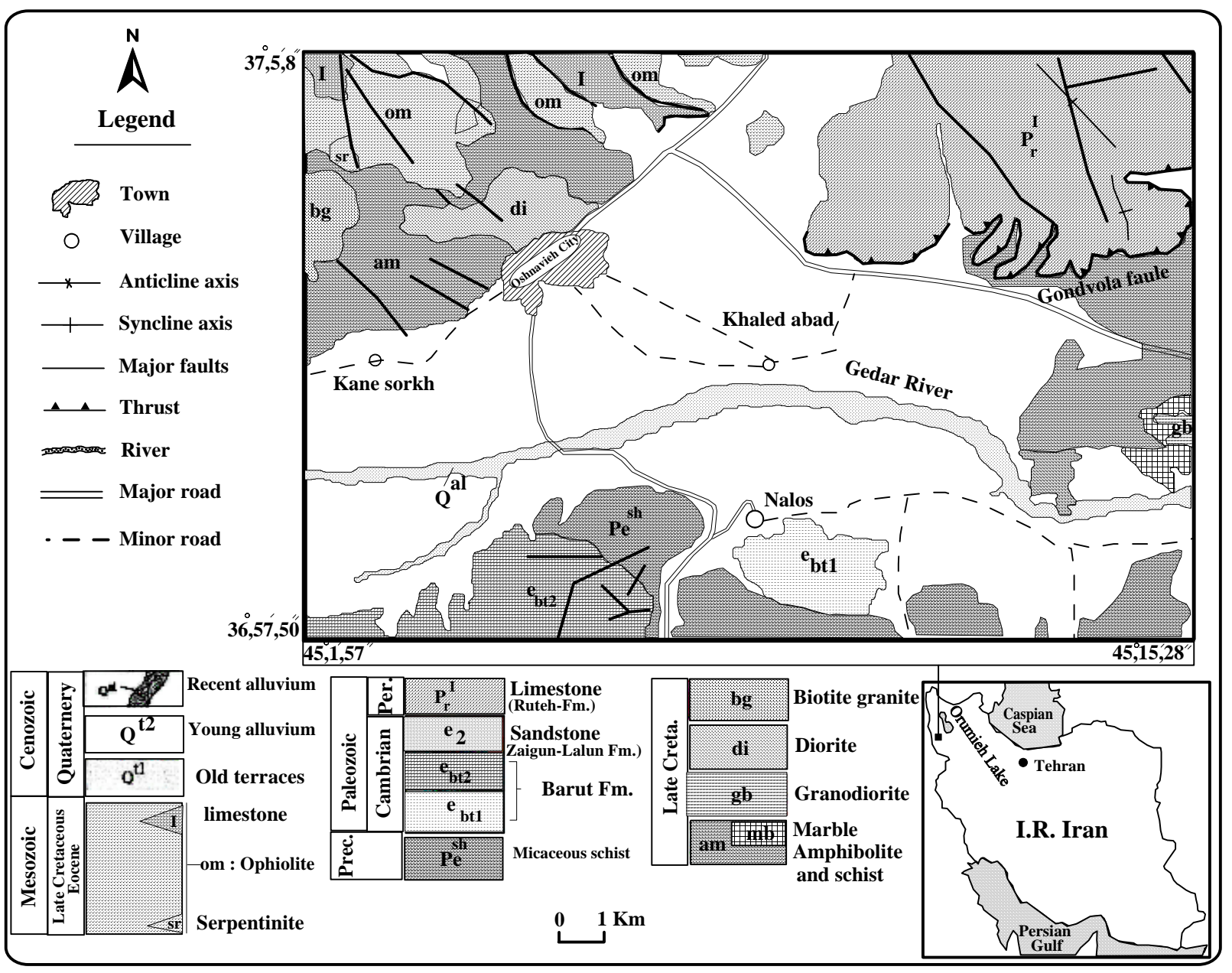

Figure 2. Location of study area showing geology and hydrogeology units 
Oshnavieh aquifer is occurred in Quaternary sediments, which are distinguished by horizontal and vertical exchange of various lithological units. It is composed of Pleistocene and Holocene gravel-sand sediments and with silt-clay interbreeds. From field work and observations, groundwater occurs in the study area in two main water-bearing layers, a lower confined aquifer and an upper unconfined aquifer. Groundwater recharge is from rainfall. In the study area groundwater is an important source for domestic water supply. Groundwater and surface water of Gedar rivers use for agriculture uses. According to Azarbaijan Regional Water Authority [22], 122 deep and 253 shallow active pumping wells operate in the aquifer. The water abstraction from the Oshnavieh aquifer during the 2003-2004 is about 30.738 million $\mathrm{m}^{3}$ and presented in Table 2. The hydraulic properties of Oshnavieh aquifer was determined using pumping tests data. The Oshnavieh aquifer is characterized by transmissivity that varies from $500-3000 \mathrm{~m}^{2} /$ day and specific yield of about $3 \times 10^{-2}$ [22]. One of the main imperative approaches for the identification of groundwater flow directions is the water level contour map, which has been used as a basis for evaluating groundwater recharge. Hence, water heads in meters above sea level (a.s.1.) in each piezometr were used to construct the piezometric surface contour map using the Surfer Software. The groundwater level contour map shown on Figure 3 summarizes the distribution of piezometric head in the aquifer system within the study area. The general groundwater flow direction in the aquifer is from $\mathrm{W}$ to $\mathrm{E}$, and depth to water table varies from 1.8 to $24.75 \mathrm{~m}$ below ground level (Figure 4). Seasonal groundwater level fluctuations indicate that the water table tends to rise during November and April to reach peak in May and declines from January onwards to reach minimum in September [21].

\subsection{Groundwater Chemistry}

The chemical composition of groundwater results from the geochemical processes occurring as water reacts with the geologic materials which it flows [23]. The water quality analyses included all major anions, cations, nitrate, phosphate, ammonia, iron and fluorine. The allover groundwater $\mathrm{pH}$ and electrical conductivity (EC) values of the study area are ranging from 7.1 to 8.4 and 290 to $990 \mu \mathrm{S} \mathrm{cm}^{-1}$, respectively. Total dissolved solids (TDS) in the study area vary between 182 to $582 \mathrm{mg} / \mathrm{l}$. The groundwater in the study area falls under fresh (TDS $<1$, $000 \mathrm{mg} / \mathrm{l}$ ) types of water [2]. The total hardness (as $\mathrm{CaCO}_{3}$ ) ranges from 125 to $448 \mathrm{mg} / \mathrm{l}$.

Table 2. Total Abstraction from Groundwater and springs during 2004

\begin{tabular}{ccccccc}
\hline $\begin{array}{c}\text { Water } \\
\text { Re- } \\
\text { source }\end{array}$ & Num. & $\begin{array}{c}\text { Min.Dis- } \\
\text { charge(lit/s) }\end{array}$ & $\begin{array}{c}\text { Max.Dis- } \\
\text { charge(lit/s) }\end{array}$ & $\begin{array}{c}\text { Annual Dis- } \\
\text { charge(MCM) }\end{array}$ & $\begin{array}{c}\text { Antural } \\
\text { uses } \\
(\mathrm{MCM})\end{array}$ & $\begin{array}{c}\text { Drinking } \\
\text { uses } \\
(\mathrm{MCM})\end{array}$ \\
\hline Springs & 23 & 1.5 & 35 & 6.927 & 6.341 & 0.585 \\
Wells & 375 & 2.4 & 44 & 23.811 & 19.26 & 4.55 \\
Total & 893 & - & - & 30.738 & 25.601 & 5.135 \\
\hline
\end{tabular}

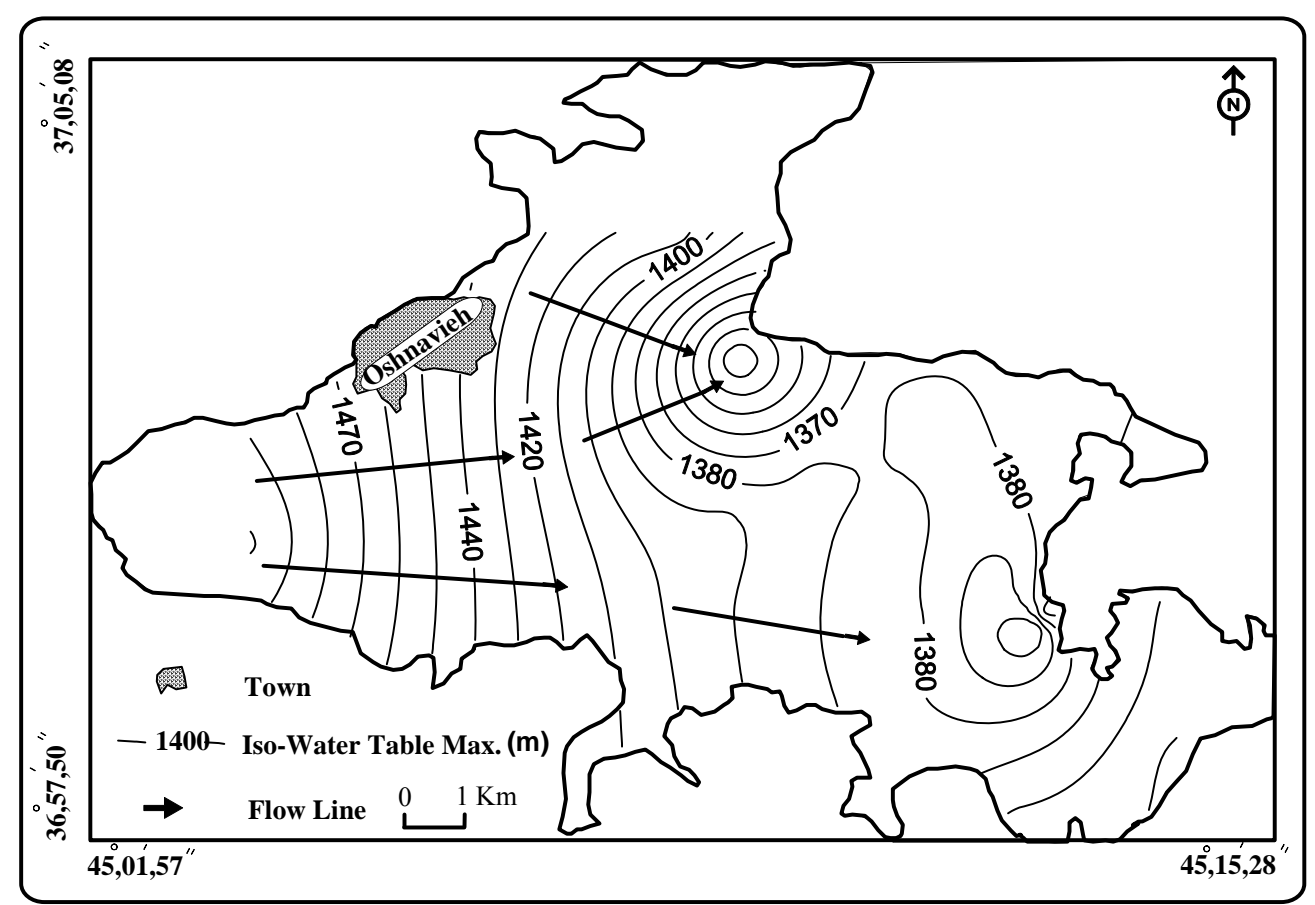

Figure 3. Groundwater level contour map of the aquifer system in the Oshnavieh plain (in meters above mean sea level) 


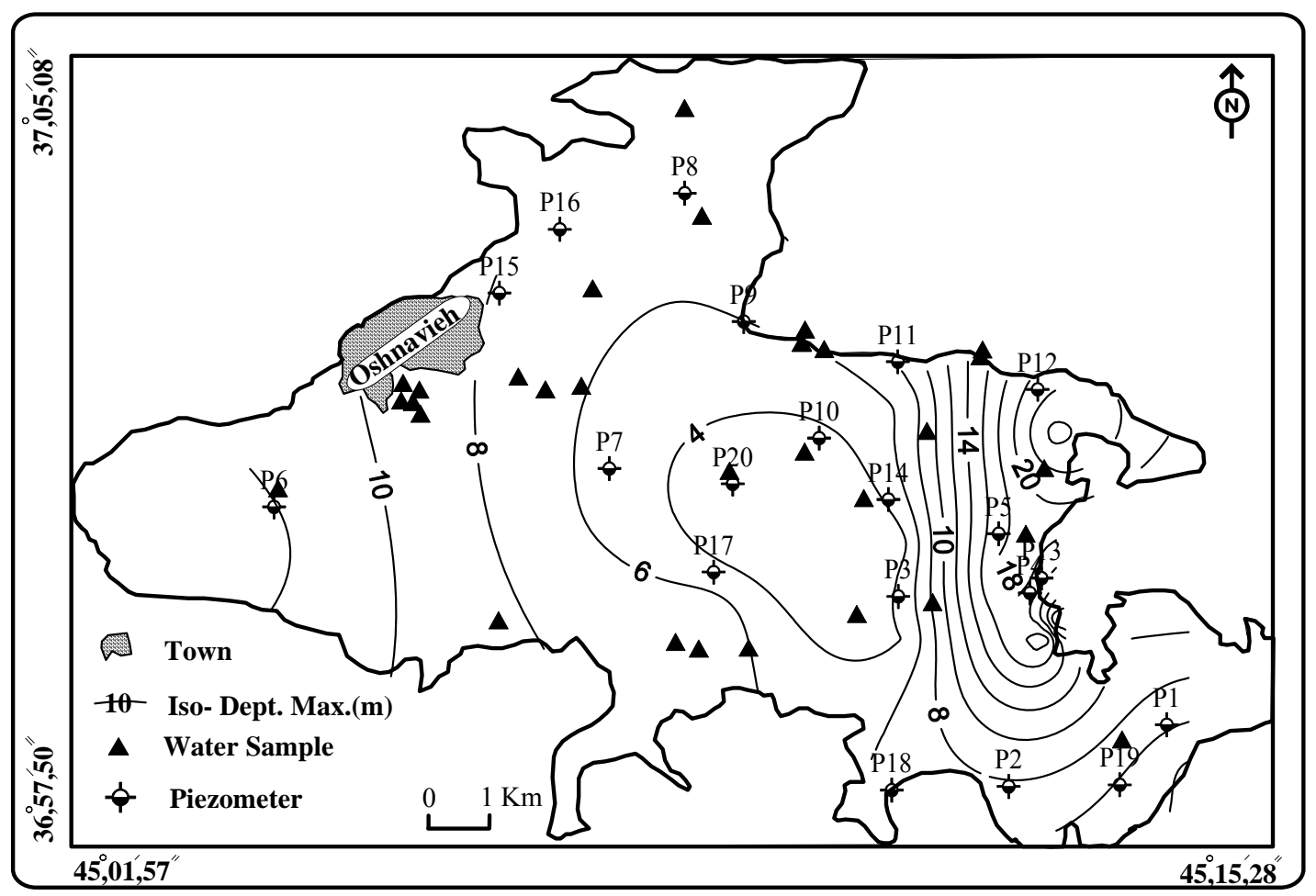

Figure 4. Depth groundwater contour map of the aquifer system in the Oshnavieh plain (in meters below ground level) and location of groundwater samples

In the study area, the $\mathrm{Na}$ and $\mathrm{K}$ concentrations in groundwater range from 2 to 52 and 0 to $11.7 \mathrm{mg} / \mathrm{l}$, respectively. The concentrations of calcium range from 20 to $142 \mathrm{mg} / \mathrm{l}$, which is derived from calcium rich minerals like feldspars, pyroxenes and amphiboles. The major source of magnesium $(\mathrm{Mg})$ in the groundwater is due to ion exchange of minerals in rocks and soils by water. The concentrations of $\mathrm{Mg}$ and $\mathrm{HCO}_{3}$ ions found in the groundwater samples of study area are ranged from $12-51$ and 140 to $506 \mathrm{mg} / \mathrm{l}$ respectively. The concentration of chloride ranges from 3.5 to $43 \mathrm{mg} / \mathrm{l}$ and increases from the recharge to discharge area. Sulfate varies from 8 to $48 \mathrm{mg} / \mathrm{l}$. The nitrate concentration in May 2006 groundwater samples range from $8 \mathrm{mg} / \mathrm{l}$ to $62 \mathrm{mg} / \mathrm{l}$ with an average value of $16.6 \mathrm{mg} / \mathrm{l}$. The source of nitrate in area is $\mathrm{N}$ fertilizers (commonly urea, nitrate or ammonium compounds) that are used for agricultural practices. Fluoride is one of main trace elements in groundwater, which generally occurs as a natural constituent. Bedrock containing fluoride minerals is generally responsible for high concentration of this ion in groundwater $[24,25]$. The concentration of fluoride in groundwater of the study area varies between 0.11-0.42 mg/l during May 2006 with an average value of $0.22 \mathrm{mg} / \mathrm{l}$ and all samples groundwater in study area are suitability for drinking. Figure 5 shows that $\mathrm{Ca}, \mathrm{Mg}$ and $\mathrm{HCO}_{3}$ are dominant cations and anion, respectively. A further illustration of this is shown in Figure 5 where the median values of $\mathrm{HCO}_{3}$ exceeded $50 \%$ of total anions in milli-equivalent unit. The abundance of the major ions in groundwater is in following order: $\mathrm{Ca}>\mathrm{Mg}>\mathrm{Na}>\mathrm{K}$ and $\mathrm{HCO}_{3}>\mathrm{SO}_{4}>\mathrm{Cl}>\mathrm{NO}_{3}>\mathrm{CO}_{3}$. Minimum, maximum and average values of physical and chemical parameters of groundwater samples are presented in Table 3. The concentration of dissolved ions in groundwater samples are generally governed by lithology, nature of geochemical reactions and solubility of interaction rocks. The functional sources of dissolved ions can be broadly assessed by plotting the samples, according to the variation in the ratio of $\mathrm{Na} /(\mathrm{Na}+\mathrm{Ca})$ and $\mathrm{Cl} /\left(\mathrm{Cl}+\mathrm{HCO}_{3}\right)$ as a function of TDS [26]. The Gibbs plot of data from study area (Figure 6) indicates that rock is the dominant processes controlling the major ion composition of groundwater.

\subsection{Saturation Index}

Saturation indexes are used to evaluate the degree of equilibrium between water and minerals. Changes in saturation state are useful to distinguish different stages of hydrochemical evolution and help identify which geochemical reactions are important in controlling water chemistry [27-29]. The saturation index of a mineral is obtained from Equation (1) [30]. 
Table 3. Minimum, maximum and average values of physical and chemical parameters of groundwater samples

\begin{tabular}{|c|c|c|c|c|}
\hline Parameters & Units & Minimum & Maximum & Average \\
\hline $\mathrm{pH}$ & - & 7.1 & 8.4 & 7.52 \\
\hline $\mathrm{EC}$ & $\mathrm{S} / \mathrm{cm} \mu$ & 290 & 910 & 592 \\
\hline TDS & $\mathrm{mg} / 1$ & 182 & 582 & 374 \\
\hline $\mathrm{Na}$ & $\mathrm{mg} / \mathrm{l}$ & 2.63 & 34.78 & 7.14 \\
\hline $\mathrm{K}$ & $\mathrm{mg} / \mathrm{l}$ & 0 & 11.7 & 1.91 \\
\hline $\mathrm{Ca}$ & $\mathrm{mg} / \mathrm{l}$ & 20 & 142 & 45.16 \\
\hline $\mathrm{Mg}$ & $\mathrm{mg} / \mathrm{l}$ & 12 & 51 & 25.9 \\
\hline $\mathrm{Cl}$ & $\mathrm{mg} / \mathrm{l}$ & 3.5 & 43 & 17.97 \\
\hline $\mathrm{HCO}_{3}$ & $\mathrm{mg} / \mathrm{l}$ & 140 & 506 & 297.6 \\
\hline $\mathrm{CO}_{3}$ & $\mathrm{mg} / \mathrm{l}$ & 0 & 60 & 2.1 \\
\hline $\mathrm{SO}_{4}$ & $\mathrm{mg} / \mathrm{l}$ & 8 & 48 & 23.75 \\
\hline TH & $\mathrm{mg} / \mathrm{l}$ & 125 & 448 & 294 \\
\hline SAR & - & 0.074 & 1.8 & 1.25 \\
\hline$\% \mathrm{Na}$ & $\%$ & 2.63 & 34.78 & 7.14 \\
\hline $\mathrm{RSC}$ & meq/1 & -2.93 & 2.3 & -1.01 \\
\hline PI & $\%$ & 30 & 66 & 42.9 \\
\hline CAI,1 & meq/1 & -0.7 & 0.64 & -0.33 \\
\hline CAI,2 & meq/1 & -0.44 & 0.37 & -0.18 \\
\hline SI calcite & - & -0.82 & 0.12 & -0.24 \\
\hline $\mathrm{SI}_{\text {dolomite }}$ & - & -1.84 & -0.12 & -0.62 \\
\hline $\mathrm{SI}_{\text {gypsum }}$ & - & -2.82 & -1.77 & -2.26 \\
\hline SI anhydrate & - & & & \\
\hline EC: Electrical conductivity & & RSC: Residual sodium carbonate & & \\
\hline TDS: Total dissolved solids & & PI: Permeability index & & \\
\hline TH: Total hardness & & CAI: Chloro alkaline index & & \\
\hline SAR: Sodium adsorption ratio & & SI: Saturation index & & \\
\hline
\end{tabular}
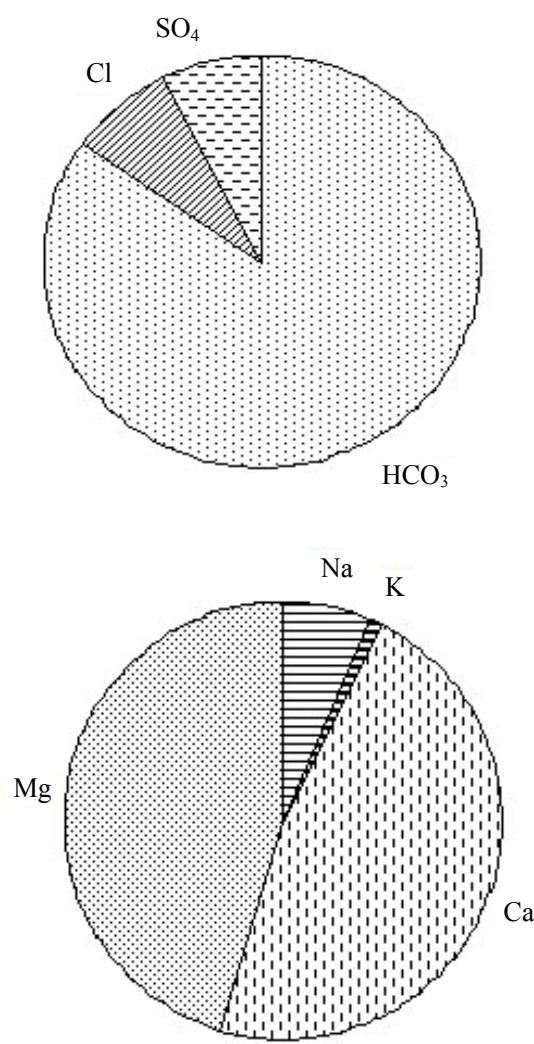

Figure 5. Pie diagram of median values of major ions

$$
\mathrm{SI}=\log (\mathrm{IAP} / \mathrm{Kt})
$$

where IAP is the ion activity product of the dissociated chemical species in solution, Kt is the equilibrium solubility product for the chemical involved at the sample temperature. An index (SI), less than zero, indicate that the groundwater is undersaturated with respect to that particular mineral. Such a value could reflect the character of water from a formation with insufficient amount of the mineral for solution or short residence time. An index (SI), greater than zero, specifies that the groundwater being supersaturated with respect to the particular mineral phase and therefore incapable of dissolving more of the mineral. Such an index value reflects groundwater discharging from an aquifer containing ample amount of the mineral with sufficient resident time to reach equilibrium. Nonetheless, super saturation can also be produced by other factors that include incongruent dissolution, common ion effect, and evaporation, rapid increase in temperature and $\mathrm{CO}_{2}$ exsolution [23,29]. In Table 2 the SI for calcite, dolomite, anhydrate and gypsum are shown. Figure 7 shows the plots of SI against TDS for all the investigated water. Nearly all water samples were saturated to undersaturate with respect to calcite, dolomite and aragonite and all samples undersaturated with respect to gypsum and anhydrite, suggesting that these carbonate mineral phases may have influenced the chemical composition of the study area. In $\mathrm{Ca}-\mathrm{HCO}_{3}$ water type the 

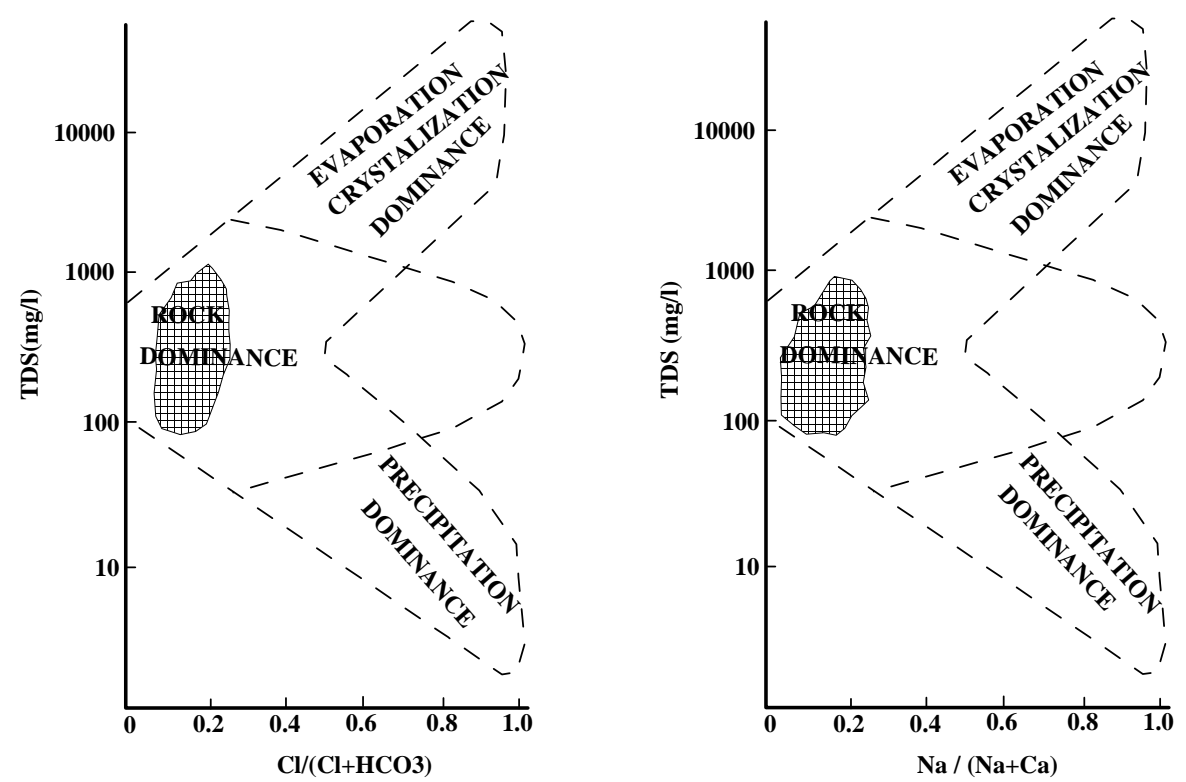

Figure 6. Mechanisms governing groundwater chemistry (after gibbs, 1970)
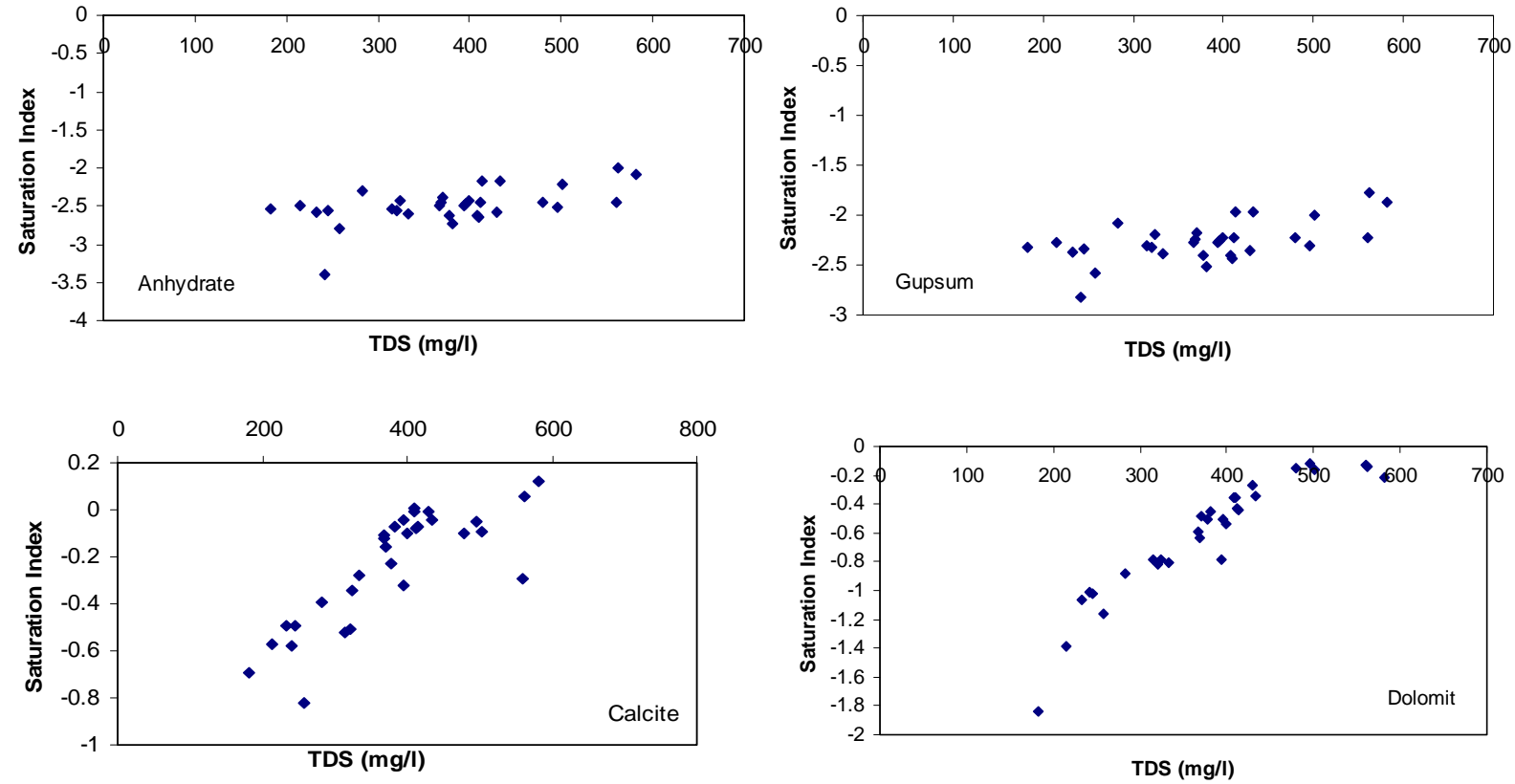

Figure 7. Plots of saturation indexes with respect to some carbonate minerals against total dissolved solids (TDS)

mean values of $\mathrm{SI}_{\mathrm{cal}}, \mathrm{SI}_{\mathrm{dol}}, \mathrm{SI}_{\mathrm{gyp}}$, $\mathrm{SI}_{\text {anhy }}$ are $-0.24,-0.617$, -2.26 and -2.49 , respectively.

\subsection{Hydrochemical Facies}

The values obtained from the groundwater samples analyzing, and their plot on the Pipers diagrams [31] reveal that the dominant cation is $\mathrm{Ca}$ and the anion is $\mathrm{HCO}_{3}$. In the study area, the major groundwater type is $\mathrm{Ca}-\mathrm{HCO}_{3}$ and $\mathrm{Ca}-\mathrm{Mg}-\mathrm{HCO}_{3}$ (Figure 8). Chadha [32] has proposed new diagram for geochemical data presentations. The proposed diagram is a modification of Piper diagram with a view to extend its applicability in representing water analysis in the possible simplest way. Results of analyses were plotted on the proposed diagram to test its applicability for geochemical classification of groundwater and to study hydrochemical processes (Figure 9). The plot shows that all of the groundwater samples fall under the subdivision of alkaline earths exceeds alkali metals and weak acidic anions exceed strong acidic anions ( $\mathrm{Ca}-\mathrm{Mg}-\mathrm{HCO}_{3}$ water type). 


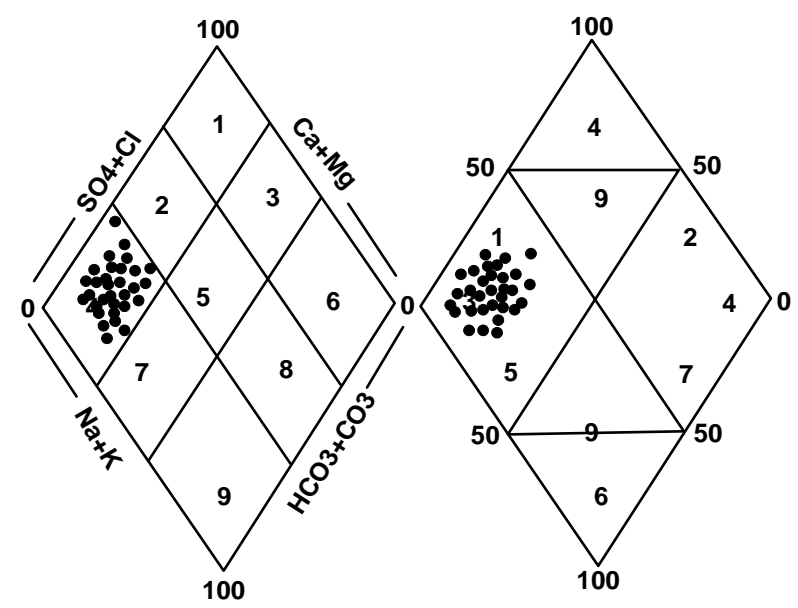

Figure 8. Chemical facies of groundwater in piper diagram

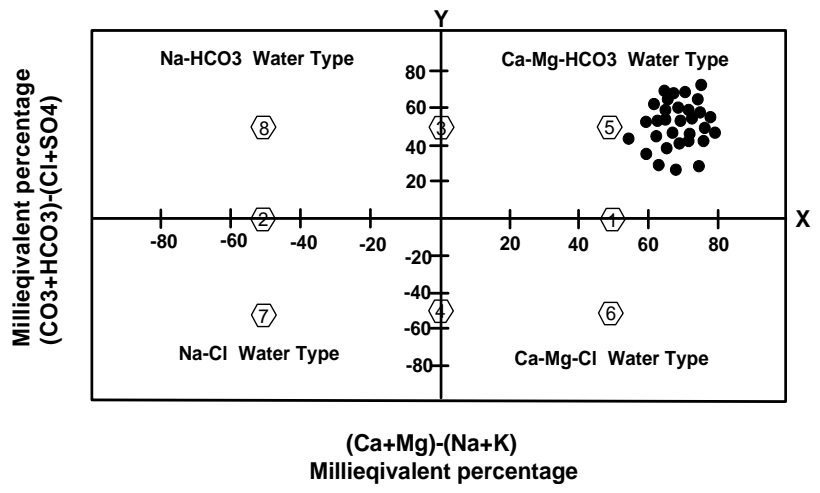

Figure 9. Diagram showing geochemical classification and hydrochemical parameters of groundwater (after chadha, 1999)

\subsection{Drinking and Irrigation Water Quality}

The analytical results have been evaluated to ascertain the suitability of groundwater of the study area for drinking and agricultural uses. The drinking water quality is evaluated by comparing with the specifications of TH and TDS set by the World Health Organization $[33,34]$. According to WHO specification TDS up to $500 \mathrm{mg} / 1$ is the highest desirable and up to $1500 \mathrm{mg} / \mathrm{l}$ is maximum permissible (Table 4). Based on this classification, $87 \%$ of samples are belonging to highest desirable category and remaining samples are belonging to maximum permissible category. The hardness values range from 125 to $448 \mathrm{mg} / 1$ during May 2006. The classification of groundwater based on total hardness [35] (Table 5) shows that 59\% of the groundwater samples fall in the very hard water category, 35\% hard category and remaining samples fall in moderately hard category(Table 5). Maximum allowable limit of $\mathrm{TH}$ for drinking is $500 \mathrm{mg} / \mathrm{l}$ and the most desirable limit is $100 \mathrm{mg} / \mathrm{l}$ as per the WHO international standard. Based on this classification it in
Table 4. Groundwater samples of the study area exceeding the permissible limits prescribed by WHO for drinking purposes

\begin{tabular}{lccc}
\hline & \multicolumn{2}{c}{ WHO international standard (1971, 1983) } \\
\cline { 2 - 4 } Parameters & $\begin{array}{c}\text { Most } \\
\text { desirable } \\
\text { limits }\end{array}$ & $\begin{array}{c}\text { Maximum } \\
\text { Allowable } \\
\text { limits }\end{array}$ & $\begin{array}{c}\text { Amount in } \\
\text { Groundwater } \\
\text { samples }\end{array}$ \\
\hline $\mathrm{PH}$ & $7-8.5$ & 9.2 & $7.1-8.4$ \\
$\mathrm{TDS}(\mathrm{mg} / \mathrm{l})$ & 500 & 1500 & $182-582$ \\
$\mathrm{TH}(\mathrm{mg} / \mathrm{l})$ & 100 & 500 & $125-448$ \\
$\mathrm{Na}(\mathrm{mg} / \mathrm{l})$ & - & 200 & $2-52$ \\
$\mathrm{Ca}(\mathrm{mg} / \mathrm{l})$ & 75 & 200 & $20-142$ \\
$\mathrm{Mg}(\mathrm{mg} / \mathrm{l})$ & 50 & 150 & $12-51$ \\
$\mathrm{Cl}(\mathrm{mg} / \mathrm{l})$ & 200 & 600 & $3.5-43$ \\
$\mathrm{SO}(\mathrm{mg} / \mathrm{l})$ & 200 & 400 & $8-48$ \\
$\mathrm{NO}(\mathrm{mg} / \mathrm{l})$ & 45 & - & $8-62$ \\
$\mathrm{NH}(\mathrm{mg} / \mathrm{l})$ & 0.05 & 0.5 & $0-0.05$ \\
$\mathrm{~F}(\mathrm{mg} / \mathrm{l})$ & - & 1.5 & $0.115-0.425$ \\
$\mathrm{Fe}(\mathrm{mg} / \mathrm{l})$ & 0.1 & 1 & $0-0.141$ \\
\hline
\end{tabular}

Table 5. Suitability of groundwater based on hardness

\begin{tabular}{cl}
\hline $\begin{array}{c}\text { Total hardness } \\
\text { as } \mathrm{CaCO}_{3}(\mathrm{mg} / 1)\end{array}$ & Water class \\
\hline$<75$ & Soft \\
$75-150$ & Moderately hard \\
$150-300$ & Hard \\
$>300$ & Very hard \\
\hline
\end{tabular}

dicates that all of the groundwater samples are not exceed the maximum allowable limits.

Salinity and indices such as, sodium absorption ratio (SAR), sodium percentage ( $\mathrm{Na} \%)$, residual sodium carbonate (RSC), and permeability index (PI) are important parameters for determining the suitability of groundwater for agricultural uses [36,37]. Electrical conductivity is a good measure of salinity hazard to crops as it reflects the TDS in groundwater. The US Salinity Laboratory [38] classified ground waters on the basis of electrical conductivity (Table 6). Based on this classification, 16\% of samples are belonging to the doubtful category and 84\% to good category. Sodium adsorption ratio (SAR) is an important parameter for determining the suitability of groundwater for irrigation because it is a measure of alkali/sodium hazard to crops [9]. SAR is defined by

Table 6. Classification of groundwater for irrigation based on EC, SAR

\begin{tabular}{lcc}
\hline \multicolumn{1}{c}{$\begin{array}{c}\text { Quality of } \\
\text { water }\end{array}$} & $\begin{array}{c}\text { Electrical conductivity } \\
(\mathrm{S} / \mathrm{cm})\end{array}$ & $\begin{array}{c}\text { Sodium adsorption } \\
\text { ratio(SAR) }\end{array}$ \\
\hline Excellent & $<250$ & $<10$ \\
Good & $250-750$ & $10-18$ \\
Doubtful & $750-2250$ & $18-26$ \\
Unsuitable & $>2250$ & $>26$ \\
\hline
\end{tabular}


Karanth [39] as Equation (2).

$$
\mathrm{SAR}=\mathrm{Na} /[(\mathrm{Ca}+\mathrm{Mg}) / 2]^{1 / 2}
$$

where all ionic concentrations are expressed in meq/l. The SAR values range from 0.074 to 1.84 and according to the Richards [40] classification based on SAR values (Table 6), all of samples are belong to the excellent category. SAR can indicate the degree to which irrigation water tends to enter into cation-exchange reactions in soil. Sodium replacing adsorbed calcium and magnesium is a hazard as it causes damage to the soil structure and becomes compact and impervious [37]. The analytical data plotted on the US salinity diagram [40] illustrates that $77 \%$ of the groundwater samples fall in the field of $\mathrm{C} 2 \mathrm{~S} 1$, indicating medium salinity and low sodium water, which can be used for irrigation on all types of soil without danger of exchangeable sodium (Figure 10). The sodium percent $(\% \mathrm{Na})$ is obtained by the Equation (3).

$$
\% \mathrm{Na}=[\mathrm{Nark}] \times 100 /[\mathrm{Ca}+\mathrm{Mg}+\mathrm{Na}+\mathrm{K}]
$$

where all ionic concentrations are expressed in meq/l.

The Wilcox [41] diagram relating sodium percentage and total concentration shows that $\% 26$ of the groundwater samples fall in the field of good to permissible and $74 \%$ of the groundwater samples fall in the field of excellent to good for irrigation (Figure 11).

Residual sodium carbonate (RSC) has been calculated to determine the hazardous effect of carbonate and bicarbonate on the quality of water for agricultural purpose and has been determined by the Equation (4).

$$
\mathrm{RSC}=\left(\mathrm{CO}_{3}+\mathrm{HCO}_{3}\right)-(\mathrm{Ca}+\mathrm{Mg})
$$

where all ionic concentrations are expressed in meq/l [42]. The classification of irrigation water according to the RSC values is waters containing more than $2.5 \mathrm{meq} / 1$

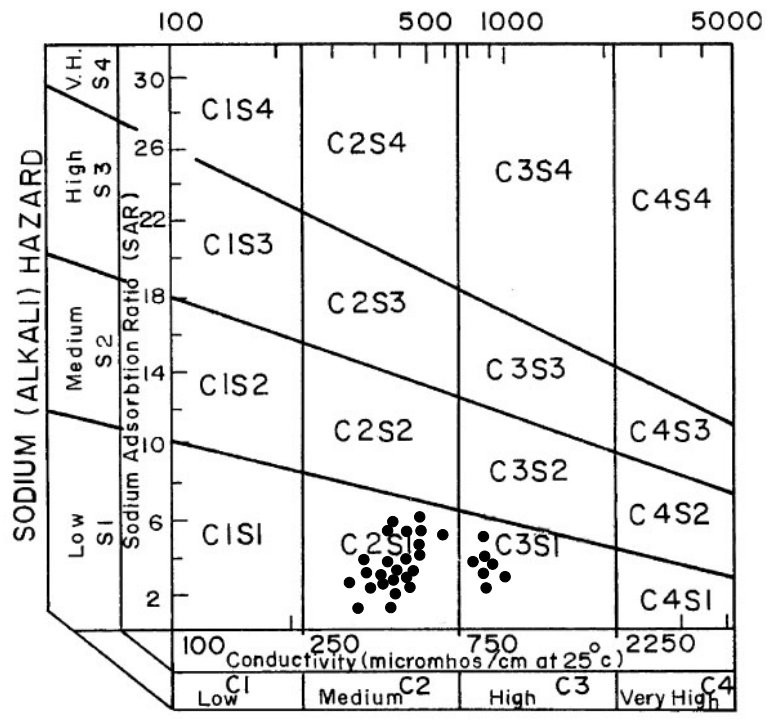

Figure 10. Rating of groundwater samples in relation to salinity and sodium hazard

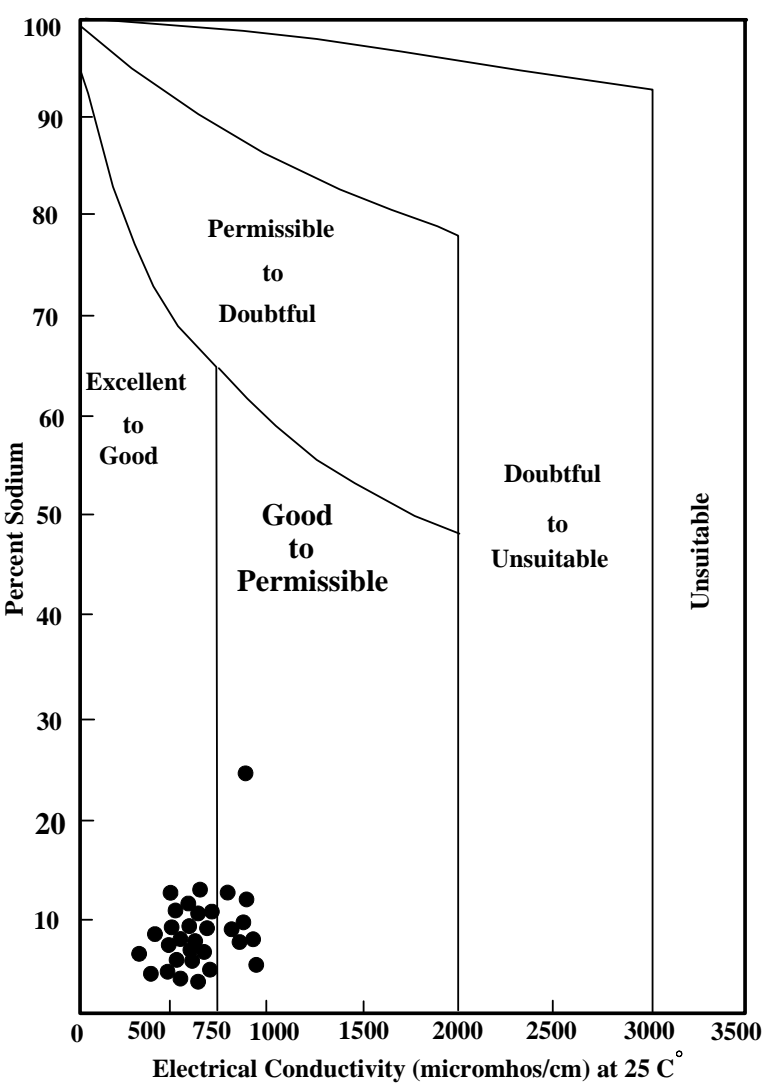

Figure 11. Rating of groundwater samples on the basis of electrical conductivity and percent sodium (after wilcox, 1955)

of RSC are not suitable for irrigation, while those having -2.93 to $2.3 \mathrm{meq} / 1$ are doubtful and those with less than $1.25 \mathrm{meq} / \mathrm{l}$ are good for irrigation. Based on this classification, all of groundwater samples belong to the good category except one sample. The permeability index (PI) values also indicate that the groundwater is suitable for irrigation. It is defined as follows (Equation (5))

$$
\mathrm{PI}=100 \times\left[\left([\mathrm{Na}]+\left[\mathrm{HCO}_{3}\right]^{1 / 2}\right) /[\mathrm{Na}]+[\mathrm{Ca}]+[\mathrm{Mg}]\right.
$$

where all the ions are expressed in meq/1 [44]. WHO [45] uses a criterion for assessing the suitability of water for irrigation based on permeability index. The PI range from $30 \%$ to $66 \%$ and the average value is about $43 \%$ during May 2006. According to PI values, the groundwater of in the study area can be designated as class II (25$75 \%$ ) that shows the groundwater in study area is suitable for irrigation purposes.

\subsection{Chloroalkaline Indices (CAI)}

It is essential to know the changes in chemical composition of groundwater during its travel in the sub-surface [45]. The Chloro-alkaline indices CAI 1, 2 are suggested by Schoeller [46], which indicate the ion exchange between the groundwater and its host environment. The 
Chloro-alkaline indices used in the evaluation of Base Exchange are calculated using the Equations $(6,7)$.

1) Chloro Alkaline Indices

$$
1=[\mathrm{Cl}-(\mathrm{Na}+\mathrm{K})] / \mathrm{Cl}
$$

2) Chloro Alkaline Indices

$$
2=[\mathrm{Cl}-(\mathrm{Na}+\mathrm{K})] /\left(\mathrm{SO}_{4}+\mathrm{HCO}_{3}+\mathrm{CO}_{3}+\mathrm{NO}_{3}\right)
$$

If there is ion exchange of $\mathrm{Na}$ and $\mathrm{K}$ from water with magnesium and calcium in the rock, the exchange is known as direct when the indices are positive. If the exchange is reverse then the exchange is indirect and the indices are found to be negative. The CAI 1, 2 are calculated for the waters of the study area as given in Table 2 . Chloro Alkaline Indices 1, 2 calculations shows that 26\% of the groundwater sample is negative and $74 \%$ positive ratios.

\section{Conclusions}

Interpretation of hydrochemical analysis reveals that the groundwater in study area is fresh, hard to very hard. The sequence of the abundance of the major ions is in the following order: $\mathrm{Ca}>\mathrm{Mg}>\mathrm{Na}>\mathrm{K}$ and $\mathrm{HCO}_{3}>\mathrm{SO}_{4}>$ $\mathrm{Cl}$. Alkali earths slightly exceed alkalis and weak acids exceed strong acids. Falling of water samples in the rock dominance area in Gibbs plot indicates the interaction between rock chemistry and the chemistry of the percolating precipitation waters in the sub-surface. The results of calculation saturation index show that the nearly all of the water samples were saturated to undersaturated with respect to carbonate minerals (calcite, dolomite and aragonite) and undersaturated with respect to sulfate minerals (gypsum and anhydrite). In the study area, the dominant hydrochemical facieses of groundwater is $\mathrm{Ca}-\mathrm{HCO}_{3}$ and $\mathrm{Ca}-\mathrm{Mg}-\mathrm{HCO}_{3}$. Distribution of the groundwater samples in rectangular diagram reveals that all of the groundwater samples fall under the calcium-magnesium-bicarbonate category. According to classification of water based on TDS, $87 \%$ of samples are belonging to highest desirable category and remaining samples are belonging to maximum permissible category. Irrigation waters classified based on SAR has indicated that $83 \%$ of samples belong to the excellent, $11 \%$ samples good and remaining samples belong to doubtful category. The Wilcox diagram relating sodium percentage and total concentration shows that $26 \%$ of the groundwater samples fall in the field of good to permissible and $74 \%$ of the groundwater samples fall in the field of excellent to good for irrigation. The analytical data plotted on the US salinity diagram illustrates that $77 \%$ of the groundwater samples fall in the field of $\mathrm{C} 2 \mathrm{~S} 1$, indicating medium salinity and low sodium water. Base on the classification of irrigation water according to the RSC values, all of groundwater samples belongs to the good category. According to PI values, the groundwater of in the study area can be designated as class II $(25-75 \%)$ that shows the groundwa- ter in study area is suitable for irrigation purposes. Assessment of water samples from various methods indicated that groundwater in study area is chemically suitable for drinking and agricultural uses. Chloroalkaline Indices 1,2 calculations shows that $26 \%$ of the groundwater sample is negative and $74 \%$ positive ratios. The positive values indicate absence of base-exchange reaction.

\section{Acknowledgements}

This study was supported by the Islamic Azad University of Urmia. The authors gratefully acknowledge the Azarbaijan Regional Water Authority for supplying the existing relevant data and also wish to thank Ms. Hajilar for the water chemistry analysis. We would like to thank Mr. E. Eliassi for their kindly help during the field visits and the collection of data.

\section{REFERENCES}

[1] P. A. Domenico and F. W. Schwartz, "Physical and chemical hydrogeology," John Wiley and Sons, New York, pp. 824, 1990.

[2] R. A. Freeze and J. A. Cherry, "Groundwater," Prentice-Hall, Englewood Cliffs, NJ, USA, 1979.

[3] B. K. Kortatsi, "Hydrochemical framework of groundwater in the Ankobra Basin, Ghana," Aquatic Geochemistry, Vol. 13, No. 1, pp. 41-74, 2007.

[4] Z. Barkic, et al., "Hydrogeology and hydrogeochemistry in the alluvial aquifer of the Zagreb area (Croatia)," Materials and Geoenvironment, Vol. 50, No. 1, pp. 75-78. 2003.

[5] A. Elkrai1, O. Kheir, L. Shu, and H. Zhenchun, "Hydrogeology of the northern Gezira area, central Sudan," Journal of Spatial Hydrology, Vol. 4, No. 2, pp. 11, 2004.

[6] N. Aghazadeh and A. A. Mogadam, "Evaluation effect of geological formation on groundwater quality in the Harzandat plain aquifer," Symposium of Geosciences of Iran, Vol. 22, pp. 392-395, 2004.

[7] M. T. Hossien, "Hydrochemical evaluation of groundwater in the Blue Nile Basin, eastern Sudan, using conventional and multivariate techniques," Hydrogeology Journal, Vol. 12, pp. 144-158, 2004.

[8] M. A. Schiavo, S. Havser, G. Gusimano, and L. Gatto, "Geochemical characterization of groundwater and submarine discharge in the south-eastern Sicily," Continental Shelf Research, Vol. 26, No. 7, pp. 826-834, 2006.

[9] T. Subramani, L. Elango, and S. R. Damodarasamy, "Groundwater quality and its suitability for drinking and agricultural use in Chithar River Basin, Tamil Nadu, India," Environmental Geology, Vol. 47, pp. 1099-1110, 2005.

[10] C. Guler and G. D. Thyne, "Hydrologic and geologic factors controlling surface and groundwater chemistry in Indian Wells-Owens Valley area, southeastern California, USA," Journal of Hydrology, Vol. 285, pp. 177-198, 
2004.

[11] E. Vazquez Sunne, X. Sanchez Vila, and J. Carrera, "Introductory review of specific factors influencing urban groundwater, an emerging branch of hydrogeology, with reference to Barcelona, Spain," Hydrogeology Journal, Vol. 13, pp. 522-533, 2005.

[12] A. Moghaddam and M. Najib, "Hydrogeologic characteristics of the alluvial tuff aquifer of northern Sahand Mountain slopes, Tabriz, Iran," Hydrogeology Journal, Vol. 14, pp. 1319-1329, 2006.

[13] M. Jalali, "Chemical characteristics of groundwater in parts of mountainous region, Alvand, Hamadan, Iran," Environmental Geology, Vol. 51, pp. 433-446, 2006.

[14] E. Khazaei, J. D. Stednick, W. E. Sanford, and J. W. Warner, "Hydrochemical changes over time in the Zahedan aquifer, Iran," Environmental Monitoring and Assessment, 2006.

[15] J. D. Hem, "Study and interpretation of the chemical characteristics of natural water," US Geological Survey Water-Supply Paper, 1970.

[16] H. Schoeller, "Geochemistry of groundwater. An international guide for research and practice," UNESCO, Chapter 15, pp. 1-18, 1967.

[17] APHA, "Standard methods for the examination of water and wastewater," 19th Edition, American Public Health Association. Washington, D.C., pp. 1467, 1995.

[18] D. L. Parkhurst and C. A. J. Appelo, "User's guide to PHREEQC (ver. 2)-A computer program for speciation, batch-reaction, one-dimensional transport, and inverse geochemical calculations," US Geological Survey Water-Resources Investment Report, pp. 99-4259, 1999.

[19] M. H. Nabavi, "Preface geology of Iran," (in Persian), Geology Survey Iran, 1976.

[20] A. Aghanabati, "Geology of Iran," (in Persian), Geological Survey of Iran, pp. 586, 2004.

[21] N. Aghazadeh, "Evaluation quality and quantity groundwater of the Oshnavieh plain aquifer," (in Persian), Islamic Azad University of Urmia, Iran, pp. 128, 2007.

[22] Azarbaijan Regional Water Authority, "Evalution of groundwater in Oshnavieh and Naghadeh plain," (in Persian) Azarbaijan Regional Water Authority, Urmia, Iran, 2004.

[23] C., A., J. Appelo and D. Postma, "Geochemistry, groundwater and pollution," Balkema, Rotterdam, pp. 536, 1996.

[24] A. Bardsen, et al., "Variability in fluoride content of subsurface water reservoirs," Acta Odontologica Scandinavica, Vol. 54, pp. 343-347, 1996.

[25] W. W. Wenzel and W. E. H. Blum, "Fluoride speciation and mobility in fluoride contaminated soil and minerals," Journal of Soil Science, Vol. 153, pp. 357-364, 1992.

[26] R. J. Gibbs, "Mechanisms controlling world water chemistry," Science, Vol. 17, pp. 1088-1090, 1970.

[27] M. Coetsiers and K. Walraevens, "Chemical characterization of the Neogene Aquifer, Belgium," Hydrogeology Journal, Vol. 14, pp. 1556-1568, 2006.
[28] J. I. Drever, "The geochemistry of natural waters," Prentice-Hall, New Jersey, pp. 436, 1997.

[29] D. Langmuir, "Aqueous environmental geochemistry," Prentice Hall, Inc., pp. 601, 1997.

[30] R. Garrels and F. Mackenzie, "Origin of the chemical compositions of some springs and lakes," In: Ground RF (ed) Equilibrium Concepts in Natural Water Systems, American Chemical Society Publications, Washington, 1967.

[31] A. M. Piper, "A graphic procedure in the geochemical interpretation of water-analyses," Transactions, American Geophysical Union, Vol. 25, pp. 914-923, 1944.

[32] D. K. Chadha, "A proposed new diagram for geochemical classification of natural water and interpretation of chemical data," Hydrogeology Journal, Vol. 7, pp. 431439, 1999.

[33] WHO, "Guideline to drinking water quality," World Health Organization, Geneva, pp. 186, 1983.

[34] WHO, "Guidelines for drinking water quality," Recommendations, World Health Organization, Geneva, Vol. 1, pp. 130, 1984.

[35] G. N. Sawyer and D. L. McCartly, "Chemistry of sanitary engineers," 2nd ed., McGraw Hill, New York, pp. 518, 1967.

[36] S. Srinivasa Gowd, "Assessment of groundwater quality for drinking and irrigation purpose: A case study of Peddavanka watershed, Anantapur District, Andhra Pradesh, India," Environmental Geology, Vol. 48, pp. 702-712. 2005.

[37] N. J. Raju, "Hydrogeochemical parameters for assessment of groundwater quality in the upper Gunjanaeru River basin, Cuddapah District, Andhara Pradesh, South India," Environmental Geology; 2006.

[38] US Salinity Laboratory, "Diagnosis and improvement of saline and alkali soils," Agricultural Handbook, USDA, No. 60, pp. 160, 1954.

[39] K. R. Karanth, "Groundwater assessment, development and management," Tata McGraw Hill, New Delhi, pp. 720, 1987.

[40] L. A. Richards, "Diagnosis and improvement of saline alkali soils: Agriculture," Handbook, US Department of Agriculture, Washington DC, Vol. 160, pp. 60, 1954.

[41] L. V. Wilcox, "Classification and use of irrigation water," USDA, Circular, Washington, DC, USA, pp. 969, 1955.

[42] F. M. Eaton, "Significance of carbonate in irrigation water," Soil Science, Vol. 69, No. 2, pp. 123-133, 1950.

[43] H. M. Ragunath, "Groundwater," Wiley Eastern Ltd., New Delhi, pp. 563, 1987.

[44] WHO, "Health guidelines for the use of wastewater in agriculture and aquaculture," Report of a WHO Scientific Group-Technical Report Series 778, WHO Geneva, pp. 74, 1989.

[45] J. C. V. Aastri, "Groundwater chemical quality in river basins, hydrogeochemical facies and hydrogeochemical modeling," Bharathidasan University, Thiruchirapalli, Tamil Nadu, India, 1994.

[46] H. Schoeller, "Geochemistry of groundwater," In: Groundwater Studies-An International Guide for Research and Practice, UNESCO, Paris, pp. 1-18, 1977. 